\title{
Discovery of the Canker Pathogen Chrysoporthe austroafricana on Native Syzygium spp. in South Africa
}

\author{
R. N. Heath, Department of Genetics, Tree Protection Cooperative Programme (TPCP), Forestry and Agricultural \\ Biotechnology Institute (FABI); M. Gryzenhout, Department of Microbiology and Plant Pathology, TPCP, \\ FABI; J. Roux, Department of Genetics, DST/NRF Centre for Tree Health Biotechnology, TPCP, FABI; and \\ M. J. Wingfield, Department of Genetics, TPCP, FABI, University of Pretoria, Pretoria, South Africa
}

\begin{abstract}
Heath, R. N., Gryzenhout, M., Roux, J., and Wingfield, M. J. 2006. Discovery of the canker pathogen Chrysoporthe austroafricana on native Syzygium spp. in South Africa. Plant Dis. 90:433-438.

Chrysoporthe canker is one of the most important diseases of plantation-grown Eucalyptus spp. in tropical and subtropical regions worldwide. For many years, the disease was reported to be caused by the fungal pathogen Cryphonectria cubensis. Recent DNA-based studies have shown that the fungus in South Africa is not conspecific with Chr. cubensis and it was recently described in the new genus Chrysoporthe as Chrysoporthe austroafricana. Chr. austroafricana is known only from South Africa, where it causes severe cankers on Eucalyptus spp. and on ornamental Tibouchina trees, both of which have been introduced into South Africa. The origin of Chr. austroafricana is unknown, but it is possible that it expanded its host range from native trees related to Eucalyptus and Tibouchina spp. to these exotic hosts. Subsequent surveys of some indigenous South African Myrtales led to the discovery of fruiting structures resembling those of Chr. austroafricana on native Syzygium cordatum and S. guineense. The fungus from these Syzygium spp. was identified as Chr. austroafricana based on morphological characteristics and $\beta$-tubulin gene sequences. Pathogenicity trials showed that Chr. austroafricana is more virulent on exotic Eucalyptus spp. than on native $S$. cordatum. This study represents the first report of Chr. austroafricana from native hosts in South Africa and adds credence to the view that the fungus could be native to this country.
\end{abstract}

Additional keywords: Diaporthales, forestry, Myrtales

Cryphonectria cubensis (Bruner) Hodges was considered one of the most important stem canker pathogens of plantation-grown Eucalyptus spp. in tropical and subtropical parts of the world (27). The pathogen first became a threat in Brazil at a time when Eucalyptus plantation forestry was expanding (27). Much later, C. cubensis was discovered in South Africa in the late 1980s, causing basal cankers and mortality of juvenile Eucalyptus grandis clones (28).

C. cubensis has been reported from three host genera in two families of the order Myrtales. The fungus was first reported on Eucalyptus in Cuba (1). This was followed by reports on a wide range of Eucalyptus spp. (Myrtaceae) worldwide, including those from Australia (4), Asia $(5,21)$, South and Central America (9), and Africa $(6,20,29)$. C. cubensis also has been described as causing dieback of Syzygium aromaticum (L.) Merr. \& Perry (clove) (Myrtaceae) in Brazil and Indonesia (9).

Corresponding author: R. N. Heath

E-mail: ronald.heath@fabi.up.ac.za

Accepted for publication 2 September 2005.

DOI: 10.1094/PD-90-0433

(C) 2006 The American Phytopathological Society
In 2001, C. cubensis was reported on native Tibouchina urvilleana (DC.) Cogn. and T. lepidota Baill. from Colombia, where it causes girdling cankers and dieback of stems and branches of these ornamental trees (28). More recently, C. cubensis also has been found on $T$. granulosa Cogn. in northern KwaZulu-Natal, South Africa (13).

Based on sequence data for the internal transcribed spacer (ITS) region of the ribosomal DNA operon, Myburg et al. (15) showed that isolates of $C$. cubensis from South East Asia and South America group in discrete clades, with South African isolates grouping with those from South America. Biological differences between C. cubensis isolates from South Africa and the rest of the world (14) prompted subsequent studies using multiple gene trees, including the ITS and $\beta$-tubulin genes. These studies showed that the South African fungus is distinct from the fungus of the same name occurring in the rest of the world. Gryzenhout et al. (8) confirmed this fact in a later study based on morphological and DNA sequence data, and assigned C. cubensis to a new genus as Chrysoporthe cubensis Gryzen. \& M.J. Wingf. (10). Isolates from South Africa subsequently were assigned to Chr. austroafricana Gryzenhout \& M. J. Wingf. One other species was identified in the genus, but was described in the new anamorph genus for Chrysoporthe, as Chrysoporthella hodgesiana Gryzenhout \& M. J. Wingf. because its teleomorph was not seen (8).

Of the three species residing in the genus Chrysoporthe, Chr. austroafricana has been reported only from exotic Tibouchina and Eucalyptus spp. in South Africa (10). In contrast Chr. cubensis occurs on a number of native and exotic hosts residing in the Myrtales in South East Asia (5), Central Africa (20), and South America $(1,9,19)$. Chrysoporthella hodgesiana is a newly described species that occurs on Tibouchina spp. in Colombia $(8,19)$.

Very little is known regarding the origin of Chr. austroafricana in South Africa. However, the fact that the fungus is now recognized as unique and different from $C$. cubensis and is found only in South Africa does suggest that it could be native to Africa. If this were true, Chr. austroafricana could have originated on native trees and crossed to exotic Eucalyptus and Tibouchina trees. This would be the same as the case with the Eucalyptus rust pathogen Puccinia psidii that is native to species of Myrtaceae in South and Central America and that has become a serious pathogen of Eucalyptus spp. in that part of the world (3). There are various native trees in South Africa belonging to the Myrtaceae and some, such as species of Syzygium, are commonly found growing in close association with Eucalyptus plantations.

Recognition of the fact that the canker disease in South Africa is caused by a unique fungus different from Chr. cubensis has prompted speculation as to its origin. This led to surveys of native Syzygium spp. for canker pathogens similar to Chr austroafricana. These surveys led to the discovery of a fungus resembling Chr. austroafricana in the KwaMbonambi area of the KwaZulu-Natal Province. The aim of this study was to survey additional Syzygium spp. adjacent to Eucalyptus-growing areas in South Africa and to determine the occurrence of Chrysoporthe spp. on native Myrtaceae in the country. The resulting fungi were studied using morphological characteristics, comparison of $\beta$-tubulin gene sequences, and pathogenicity studies.

\section{MATERIALS AND METHODS}

Disease symptoms and collection of samples. $S$. cordatum and $S$. guineense 
trees showing signs of dieback and the formation of bark cracks and cankers were identified in the Zululand (KwaZulu-Natal Province), Tzaneen (Limpopo Province), Hazyview, and Sabie (Mpumalanga Province) areas of South Africa (Fig. 1). These symptoms were different from those observed on Eucalyptus spp. (27). Segments of bark and branches bearing fruiting bodies resembling those of Chrysoporthe spp. were collected for further analysis. The material was incubated in moist chambers to induce the production of fruiting bodies. Single conidial and ascospore isolations were made on $2 \%$ malt extract agar (MEA) (Biolab, Merck, Midrand, South Africa) and incubated at $25^{\circ} \mathrm{C}$. Isolates are maintained in the culture collection (CMW) of the Forestry and Agricultural Biotechnology Institute (FABI), University of Pretoria, South Africa. Bark specimens from the Syzygium spp. have been deposited in the herbarium of the National Collection of Fungi, Pretoria, South Africa (PREM) (Table 1).

Morphology. Bark specimens with fruiting structures collected from cankers on Syzygium spp. were compared with specimens of Chrysoporthe spp. used in previous studies $(8,13,14,29$; Table 1). For these comparisons, fruiting structures were embedded in Leica embedding medium

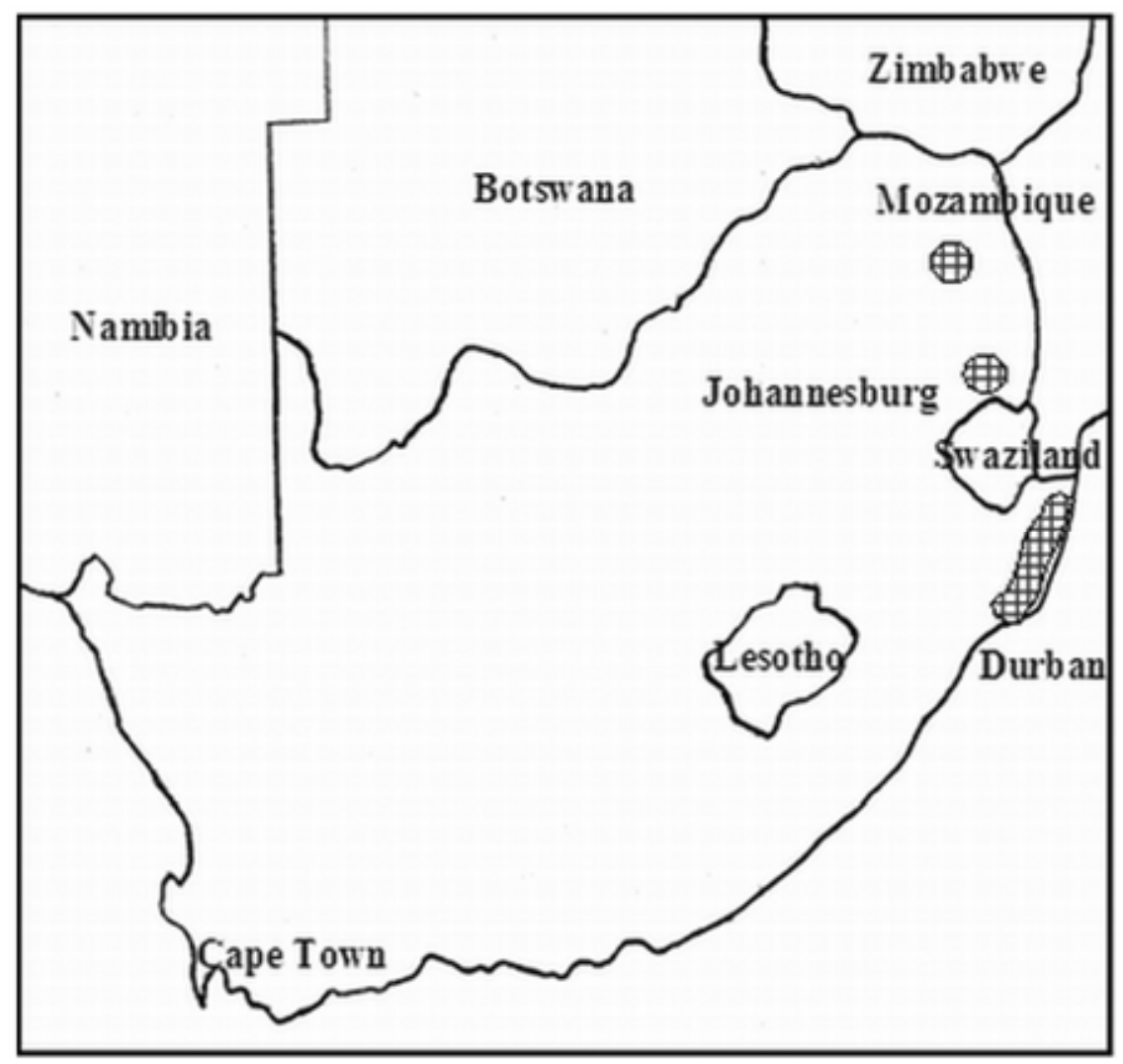

Fig. 1. Map of South Africa indicating areas where Chrysoporthe austroafricana isolates were collected. and sectioned using a Leica CM1100 cryostat (Setpoint Technologies, Johannesburg, South Africa). Specimens were sectioned at $-20^{\circ} \mathrm{C}$ to a thickness of $12 \mu \mathrm{m}$. The sectioned structures were mounted in lactophenol and subsequently studied using standard light microscopy. To obtain the sizes of fruiting structures, minimum and maximum sizes were obtained of the smallest and largest structures. Twenty measurements were taken of conidiophores, conidia, asci, and ascospores for each collection and were presented as (min-) mean - st.dev. - mean + st.dev. (-max). Color notations used were those described by Rayner (18).

DNA isolation and amplification. Isolates (Table 2) were inoculated into $1.5-\mathrm{ml}$ microcentrifuge tubes containing 3\% malt extract broth $(750 \mu \mathrm{l})$ and incubated at $25^{\circ} \mathrm{C}$ for 4 days. DNA was isolated as described by Van der Merwe et al. (24). Two $\beta$-tubulin gene regions were amplified using primer pairs $\mathrm{Bt} 1 \mathrm{a} / \mathrm{Bt} 1 \mathrm{~b}$ and $\mathrm{Bt} 2 \mathrm{a} / \mathrm{Bt} 2 \mathrm{~b}$ (7). Amplification of the $\beta$ tubulin gene regions followed the protocols of Myburg et al. (14). Amplification reactions were performed on a PerkinElmer GeneAmp polymerase chain reaction (PCR) System 9700 thermocycler (Perkin-Elmer Applied Biosystems, Inc. Foster City, CA). PCR products were visualised on a $2 \%$ agarose-ethidium bromide gel using ultraviolet light.

DNA sequencing. PCR products were purified using a High Pure PCR Product Purification Kit (Roche Diagnostic GmbH, Mannheim, Germany). DNA fragments were sequenced with the same primer pairs used in the amplification reactions. An ABI PRISM Dye Terminator Cycle Sequencing Ready Reaction Kit with AmpliTaq DNA Polymerase, FS (Perkin-Elmer, Warrington, UK) was used for the sequencing, using an ABI PRISM 3100 automated sequencer. Sequences were aligned using ClustalX (23) and manually adjusted using Sequence Navigator (version 1.0.1; Perkin-Elmer Applied BioSystems Inc.). All sequences obtained in this

Table 1. Specimens used in the morphological comparisons

\begin{tabular}{|c|c|c|c|c|c|}
\hline Herbarium no. ${ }^{a}$ & Identity & Host & Origin & Date & Collector \\
\hline PREM 58023 (holotype) & Chrysoporthe austroafricana & Eucalyptus grandis & South Africa & 1989 & M. J. Wingfield \\
\hline PREM 49379 & Chr. austroafricana & E. grandis & South Africa & 1988 & M. J. Wingfield \\
\hline PREM 49377 & Chr. austroafricana & E. grandis & South Africa & 1986 & M. J. Wingfield \\
\hline PREM 49378 & Chr. austroafricana & E. grandis & South Africa & 1987 & M. J. Wingfield \\
\hline PREM 57293 & Chr. austroafricana & E. grandis & South Africa & 2001 & M. Gryzenhout \\
\hline PREM 57357 & Chr. austroafricana & Tibouchina granulosa & South Africa & 1999 & J. Roux \\
\hline PREM 57358 & Chr. austroafricana & T. granulosa & South Africa & 1999 & J. Roux \\
\hline PREM 57474 & Chr. austroafricana & Syzygium cordatum & South Africa & 2001 & R. N. Heath \& M. Gryzenhout \\
\hline PREM 57475 & Chr. austroafricana & S. guineense & South Africa & 2001 & M. Gryzenhout \\
\hline PREM 57476 & Chr. austroafricana & S. cordatum & South Africa & 2001 & R. N. Heath \& M. Gryzenhout \\
\hline PREM 57477 & Chr. austroafricana & S. cordatum & South Africa & 2002 & R. N. Heath \& J. Roux \\
\hline PREM 57478 & Chr. austroafricana & S. cordatum & South Africa & 2002 & R. N. Heath \& J. Roux \\
\hline PREM 57479 & Chr. austroafricana & S. cordatum & South Africa & 2002 & R. N. Heath \& J. Roux \\
\hline PREM 57480 & Chr. austroafricana & S. cordatum & South Africa & 2002 & R. N. Heath \& J. Roux \\
\hline PREM 57294 & Chr. cubensis & E. grandis & Colombia & 2000 & M. J. Wingfield \\
\hline PREM 57297 & Chr. cubensis & Eucalyptus sp. & Indonesia & 2001 & M. J. Wingfield \\
\hline
\end{tabular}

a PREM, National Collection of Fungi, Pretoria, South Africa. 
study have been deposited in GenBank (Table 2).

Data analyses were performed using phylogenetic analysis using parsimony (PAUP*) version 4.0b (22). A partitionhomogeneity test (PHT) was performed using PAUP* version $4.0 \mathrm{~b}$ for the two $\beta$ tubulin gene region data sets (22). Analyses were done using the heuristic search option with tree-bisection-reconnection (TBR) branch swapping. Gaps inserted during sequence alignment were treated as fifth character (NEWSTATE). A bootstrap analysis (50\% majority rule, 1,000 replications) was done to determine the confidence levels of the tree-branching points. Previously published sequences for $\mathrm{Chr}$. austroafricana, C. cubensis, and Chrysoporthella hodgesiana $(8,13,14)$ were used for comparative purposes. Cryphonectria parasitica was used as an outgroup taxon to root the phylogenetic tree (8).

The credibility of the branch nodes was tested using Markov Chain Monte Carlo Algorithms (MCMC) (10) in Bayesian analysis (12). Random trees were obtained through 2,000,000 generations, with every 100th tree sampled. The first 9,000 trees were discarded as the burnin period. MODELTEST (17) was used to determine that a general time reversal model, including invariable sites, best fit the data set, and four MCMC chains were run simultaneously in the analysis, with three heated chains and one cold chain. The sampled trees were summarized in a consensus tree showing posterior probabilities of the branches.

Pathogenicity. In order to determine whether the fungus isolated from the Syzygium spp. was the causal agent of the can- kers and dieback observed on trees, and to consider the pathogenicity of the fungus on Eucalyptus spp., infection studies were performed. The $S$. cordatum and E. grandis trees used for inoculation had stem diameters ranging from 10 to $23 \mathrm{~mm}$ and were arranged in a completely randomized design. All trees were maintained under greenhouse conditions for a 2 -week acclimatization period prior to inoculation. The greenhouse was subjected to natural day/night conditions (approximately $13 \mathrm{~h}$ of daylight and $11 \mathrm{~h}$ of darkness) and a temperature of approximately $25^{\circ} \mathrm{C}$ was maintained.

In order to assess the reciprocal pathogenicity of isolates on $S$. cordatum and Eucalyptus spp., the fastest growing isolate from S. cordatum (CMW 9364) and an isolate (CMW 2113) from E. grandis, previously shown to represent a higher level of pathogenicity in a population of $\mathrm{Chr}$. austroafricana isolates (25), each were inoculated into the stems of $20 \mathrm{~S}$. cordatum and 20 E. grandis (clone ZG14) trees. This Eucalyptus clone was selected because it is known to be highly susceptible to infection by Chr. austroafricana and has been used previously in pathogenicity trials $(2,13)$. Ten trees per species were inoculated with sterile MEA plugs to serve as controls. Wounds were made on the stems of trees approximately $150 \mathrm{~mm}$ from the soil level, using a 10-mm-diameter cork borer. Mycelial plugs of a similar size were taken from the actively growing edges of 7-day-old cultures and placed in the wounds with the mycelium toward the cambium. Wounds were sealed with laboratory film (Parafilm "M"; American National Can, Chicago) to protect the inocu- lated fungus and cambium from desiccation.

Lesion lengths associated with the inoculations were measured after 6 weeks. To determine the variance between isolates and between trees, inoculation data were subjected to analysis of variance using the General Linear Model procedure of SAS (24). All inoculation tests were repeated and the data analyzed together. To determine whether the inoculated fungi were responsible for the lesion development, Koch's postulates were applied by reisolating from the lesions and confirming the identity of the inoculated fungi based on morphology.

\section{RESULTS}

Disease symptoms and collection of samples. A number of trees showing branch dieback and stem and branch cankers were found in all of the areas surveyed. Asexual fruiting bodies of a fungus, resembling those of Chr. austroafricana, were found on dead areas of the stems and branches of these trees. Teleomorph structures, morphologically similar to Chr. austroafricana, also were common on trees in Limpopo Province and the Zululand area. No teleomorph structures were found on trees in the Mpumalanga Province. A total of three isolates were obtained from Limpopo Province, two isolates from Mpumalanga Province, and 68 isolates from the Zululand area. Only one isolate was collected per tree.

Morphology. The fungus found on native South African Syzygium spp. had a morphology similar to that of Chr. austroafricana described from Eucalyptus spp. and T. granulosa $(8,13)$ in South Af-

Table 2. Isolates used for phylogenetic analysis and pathogenicity trials

\begin{tabular}{|c|c|c|c|c|}
\hline Culture no. ${ }^{a}$ & Isolate identity & Host & Origin & GenBank accession number \\
\hline CMW 9364 & Chrysoporthe austroafricana & Syzygium cordatum & South Africa & AY $149284^{b}$ \\
\hline CMW 9366 & Chr. austroafricana & S. cordatum & South Africa & AY $149285^{\mathrm{b}}$ \\
\hline CMW 10036 & Chr. austroafricana & S. cordatum & South Africa & AY $149286^{\mathrm{b}}$ \\
\hline CMW 10046 & Chr. austroafricana & S. cordatum & South Africa & AY $149287^{b}$ \\
\hline CMW 10076 & Chr. austroafricana & S. cordatum & South Africa & AY $149288^{b}$ \\
\hline CMW 10086 & Chr. austroafricana & S. cordatum & South Africa & AY149289b \\
\hline CMW 10092 & Chr. austroafricana & Syzygium guineense & South Africa & AY $149290^{\mathrm{b}}$ \\
\hline CMW 62 & Chr. austroafricana & Eucalyptus grandis & South Africa & AF273063; AF273458c \\
\hline CMW 2113 & Chr. austroafricana & E. grandis & South Africa & AF273067; AF273462c \\
\hline CMW 8755 & Chr. austroafricana & E. grandis & South Africa & AF273064; AF273459c \\
\hline CMW 9327 & Chr. austroafricana & Tibouchina granulosa & South Africa & $\mathrm{AF} 273060 ; \mathrm{AF} 273455^{\mathrm{c}}$ \\
\hline CMW 9328 & Chr. austroafricana & T. granulosa & South Africa & $\mathrm{AF} 273061 ; \mathrm{AF} 273456^{\mathrm{c}}$ \\
\hline CMW 9932 & Chr. austroafricana & T. granulosa & South Africa & AF273062; AF273457c \\
\hline CMW 9927 & Chrysoporthella hodgesiana & T. urvilleana & South America & AF292034; AF292037c \\
\hline CMW 9928 & Chr. hodgesiana & T. urvilleana & South America & AF292036; AF292038c \\
\hline CMW 9929 & Chr. hodgesiana & T. urvilleana & South America & AF292035; AF292038c \\
\hline CMW 8758 & Chrysoporthe cubensis & E. grandis & South America & AF273068; AF273463c \\
\hline CMW 1853 & Chr. cubensis & S. aromaticum & South America & $\mathrm{AF} 273070 ; \mathrm{AF} 273465^{\mathrm{c}}$ \\
\hline CMW 8756 & Chr. cubensis & E. grandis & Southeast Asia & AF273077; AF375606 ${ }^{\mathrm{c}}$ \\
\hline CMW 9906 & Chr. cubensis & Eucalyptus sp. & Southeast Asia & AF273069; AF273464c \\
\hline CMW 9903 & Chr. cubensis & S. aromaticum & Southeast Asia & $\mathrm{AF} 273070 ; \mathrm{AF} 273465^{\mathrm{c}}$ \\
\hline CMW 7047 & Cryphonectria parasitica & Quercus virginiana & United States & AF273469; AF273073 ${ }^{d}$ \\
\hline CMW 7048 & C. parasitica & Q. virginiana & United States & AF273470; AF273076 d \\
\hline
\end{tabular}

\footnotetext{
a Culture collection of the Forestry and Agricultural Biotechnology Institute (FABI), University of Pretoria, Pretoria, 0002, South Africa.

b $\beta$-Tubulin 1 and 2 sequence data generated in this study.

c $\beta$-Tubulin 1 and 2 sequence data obtained from Myburg et al. $(16,17)$.

d $\beta$-Tubulin 1 and 2 sequence data obtained from Venter et al. (30).
} 

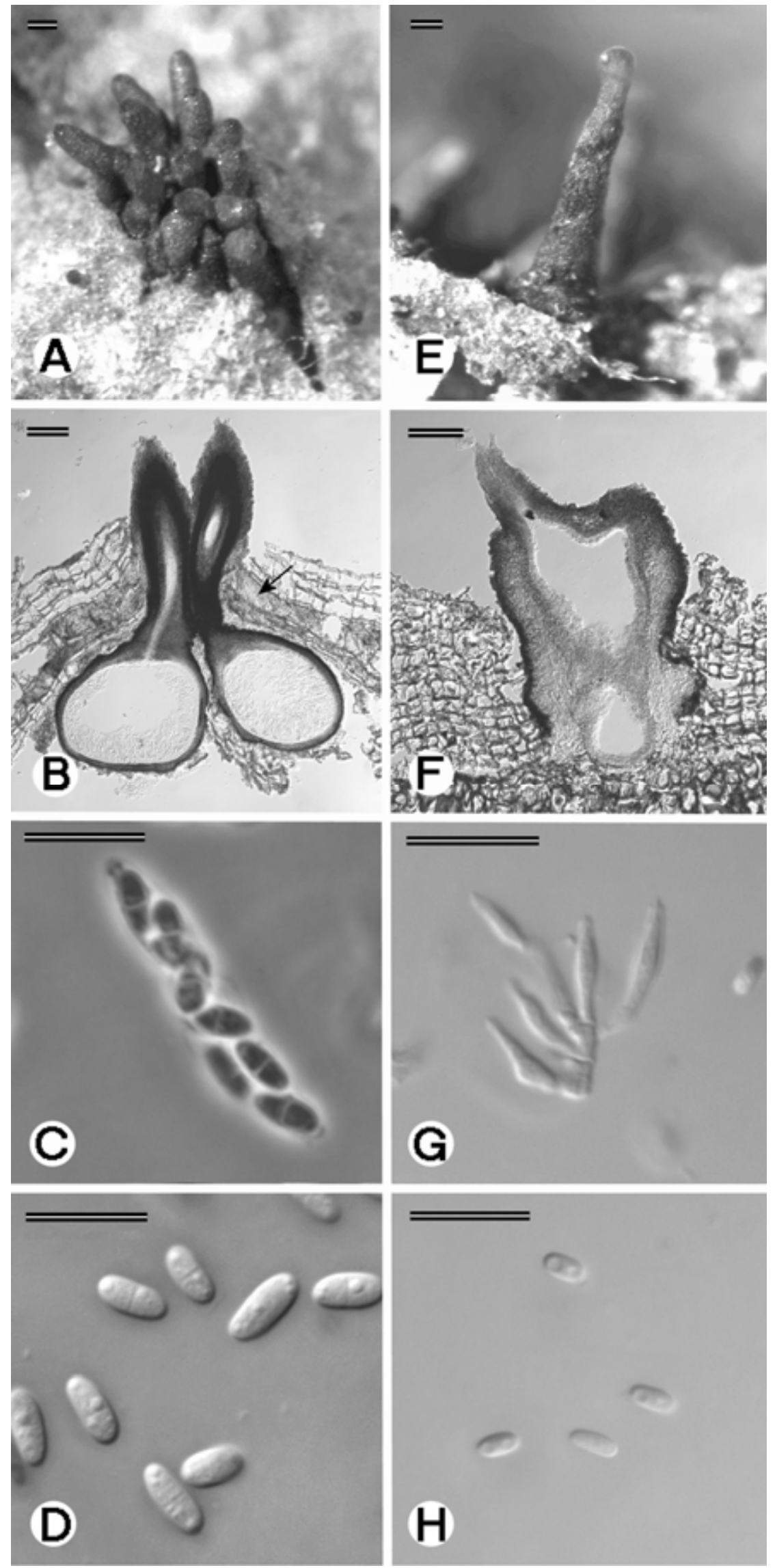

Fig. 2. Light micrographs of the fruiting structures of Chrysoporthe austroafricana from Syzygium spp. in South Africa. A, Ascoma on bark. B, Longitudinal section through ascoma showing clypeus (arrow). C, Ascus. D, Ascospores. E, Conidioma on bark. F, Longitudinal section through conidioma. G, Conidiophore. H, Conidia. Bars: A, B, E, and $\mathbf{F}=100 \mu \mathrm{m} ; \mathbf{C}, \mathbf{D}, \mathbf{G}$, and $\mathbf{H}=10 \mu \mathrm{m}$. rica. Ascomata were characterized by long perithecial necks emerging from the bark with weakly developed, predominantly prosenchymatous, cinnamon- to orangecolored stromatic tissue at the bases of the necks (Fig. 2A and B). Perithecia were semi-immersed in the bark, black, base globose, and about 250 to $320 \mu \mathrm{m}$ in diameter (Fig. 2B). Perithecial necks were periphysate, up to $1,220 \mu \mathrm{m}$ long as they emerged through the bark, and covered in umber tissue, giving them a fuscous black appearance as they extended beyond the stromata (Fig. 2B). Extended parts of the perithecial necks were about 100 to 155 $\mu \mathrm{m}$ wide, and the width of the actual perithecial neck was approximately 65 to $113 \mu \mathrm{m}$. Asci were fusoid to ellipsoid, nonstipitate, with nonamyloid refractive rings, (26-) $27-31.5(-32) \times 6$ to 7 $(-7.5) \mu \mathrm{m}$ in size, and contained eight ascospores (Fig. 2C). Ascospores were hyaline, septate, fusoid to oval, (5-) $5.5-6.5$ $(-7) \times(1.5-) 2-2.5(-3) \mu \mathrm{m}$ in size, with rounded ends (Fig. 2D), which is the morphological feature distinguishing $C h r$. austroafricana from Chr. cubensis (8).

Conidiomata were superficial to slightly immersed, pyriform to clavate (Fig. 2E and F), uni- to multilocular (Fig. 2F), and fuscous black, with an umber interior base approximately 280 to $500 \mu \mathrm{m}$ long and a base above the bark surface 60 to $370 \mu \mathrm{m}$ long and 300 to $450 \mu \mathrm{m}$ wide. One to three necks (Fig. 2E) connected to single or separate locules occurred in each structure, and these were 110 to $170 \mu \mathrm{m}$ wide. Conidiophores were hyaline, cylindrical or flask shaped with attenuated apices, frequently septate, branching irregularly, and (7.5-) 9.5 - $15.5 \mu \mathrm{m}$ long (Fig. 2G). Conidiogenous cells were phialidic, determinate, and 1 to $1.5 \mu \mathrm{m}$ wide (Fig. 2G). Conidia were exuded as bright luteous spore tendrils or droplets, hyaline, nonseptate, oblong to oval, and $3-3.5 \times 1.5 \mu \mathrm{m}$ in size (Fig. $2 \mathrm{H}$ ).

DNA sequencing. PCR amplification with the two primer pairs resulted in fragments of 537 bp (Bt1a/Bt1b) and $495 \mathrm{bp}$ $(\mathrm{Bt} 2 \mathrm{a} / \mathrm{Bt} 2 \mathrm{~b})$. The fragments were sequenced and resulted in sequences of 464 bp (Bt1a/Bt1b) and 425 bp (Bt2a/Bt2b) before alignment. After alignment, a partition homogeneity test on the two separate data sets gave a PHT value of $P=0.2$, showing that the two data sets $(\mathrm{Bt} 1 \mathrm{a} / 1 \mathrm{~b}$ and $\mathrm{Bt} 2 \mathrm{a} / 2 \mathrm{~b}$ ) were congruent and could be combined in the phylogenetic analysis. Aligned sequences of the combined data sets resulted in a data set of 976 characters, consisting of 809 constant characters, 25 parsimony-informative characters, and 142 variable characters that were parsimony uninformative. The heuristic search produced four most parsimonious trees with most variation in the clade, including the Chr. austroafricana isolates (Fig. 3). A strict bootstrap consensus tree (length of tree $=198$ steps, $\mathrm{CI}=0.889, \mathrm{RI}=0.909$, $\mathrm{RC}=0.808)$ was generated from the 100 
variable characters and most branches were well supported with high bootstrap values (Fig. 3). Posterior probability values calculated for the branch nodes were as high as the bootstrap values.

Results of the DNA sequence analysis supported the outcome of the morphological comparison, with isolates from Syzygium spp. grouping with those from $\mathrm{Ti}^{-}$ bouchina and Eucalyptus spp. in South Africa. This confirms the identification of the fungus as Chr. austroafricana (Fig. 3). The Syzygium isolates grouped within the Chr. austroafricana clade and separate from isolates in the Chr. cubensis and Chrysoporthella hodgesiana clades (bootstrap support $98 \%$, posterior probability $100 \%$ ). The larger Chrysoporthe clade grouped separately from Cryphonectria parasitica (bootstrap support $100 \%$, posterior probability $100 \%$ ).

Pathogenicity. Inoculation of $S$. cordatum and E. grandis with Chr. austroafricana resulted in lesions on both hosts within 6 weeks after inoculation (Table 3). Some of the Eucalyptus trees showed signs of decline and produced epicormic shoots on the stems within this time period. Epicormic shoots were present on some $S$. cordatum trees, but no dieback was visible.
No lesions were produced on control trees of either host. Isolates from both Syzygium and Eucalyptus spp. were more pathogenic on Eucalyptus than on $S$. cordatum $(P>$ 0.0001) (Fig. 4; Table 3). Isolates from Syzygium spp. were more pathogenic than those from Eucalyptus. The test organism was isolated consistently from the lesions on both hosts after 6 weeks.

\section{DISCUSSION}

Canker on Eucalyptus spp., caused by Chr. austroafricana (previously Cryphonectria cubensis), has been known in South Africa since 1989, and it is recognized as a serious threat to the future of plantations of these trees $(28,30)$. Recent recognition that the causal agent of this disease in South Africa, Chr. austroafricana, represents a species different from the well-known Chr. cubensis (previously known as Cryphonectria cubensis), has raised the intriguing question as to whether the fungus in South Africa might not be native to this region. Collection of Chr. austroafricana from native Syzygium spp. covering a wide natural distribution of the tree in this study provides support for this hypothesis.

Analysis of DNA sequence data as well as morphological characteristics presents

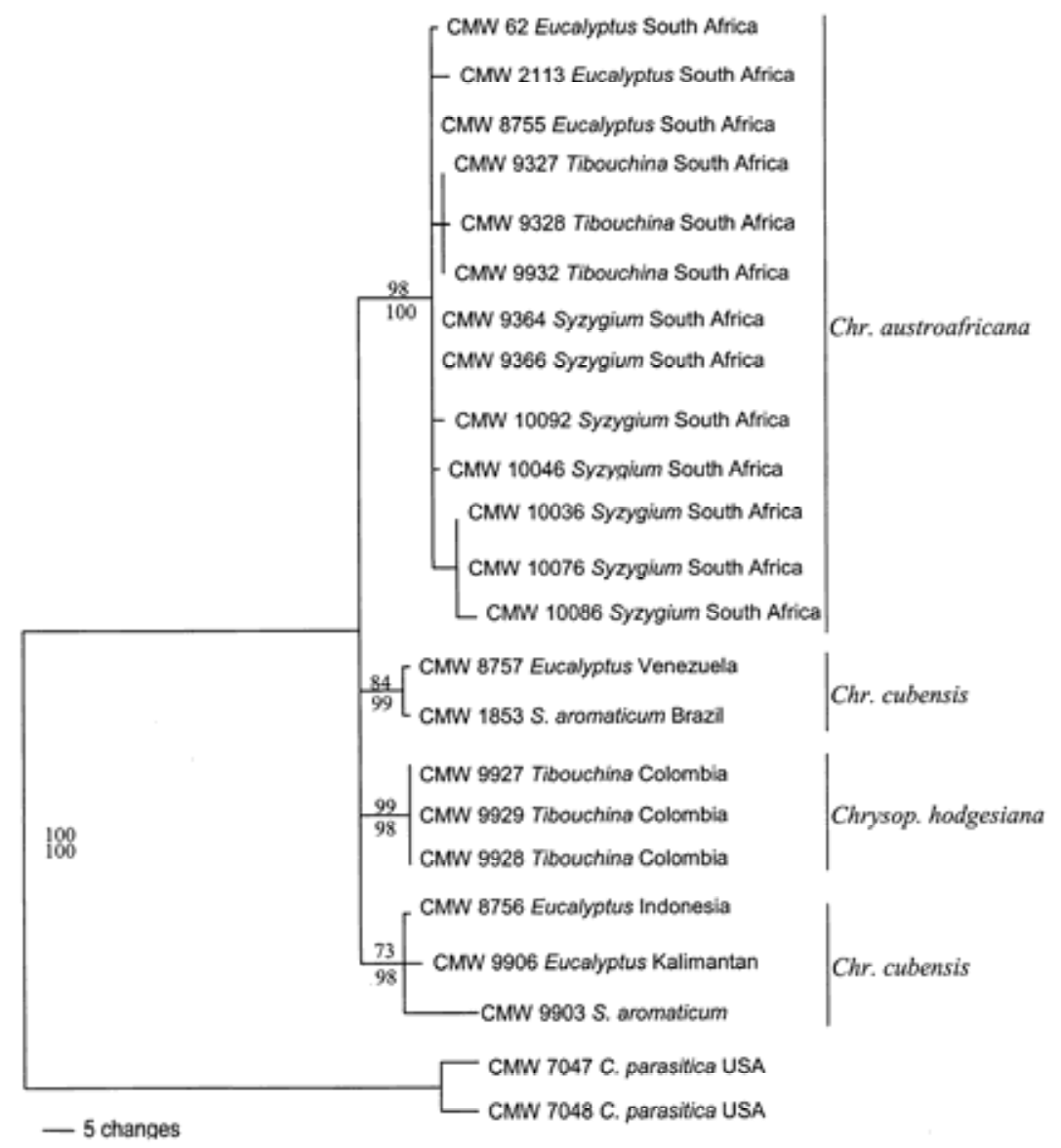

Fig. 3. Phylogenetic tree based on parsimony generated from a data set including $\beta$-tubulin gene sequence data. Strict consensus tree (length of tree $=198$ steps, $\mathrm{CI}=0.889, \mathrm{RI}=0.909, \mathrm{RC}=0.808$ ) generated from heuristic searches using parsimony. Bootstrap values (1,000 replicates) are indicated above the branches with those lower than $50 \%$ not shown. Posterior probability values are indicated below the branches. Cryphonectria parasitica was used to root the tree. robust evidence that the fungus on native Syzygium spp. is the same as that found on Eucalyptus and Tibouchina spp. in South Africa. It has been suggested previously that Chr. austroafricana, previously reported under the name Cryphonectria cubensis, was accidentally introduced into South Africa (2,26). This view was based on the fact that a South African population of the fungus showed a low genetic diversity based on vegetative compatibility groups (26). Results of the present study suggest that Chr. austroafricana is native to Southern Africa or, alternatively, that it could have been introduced into the country from an as yet unknown origin.

Collections of fungi from dieback symptoms on native Syzygium spp. were planned specifically to broadly cover the natural distribution range of these trees in South Africa. Chr. austroafricana was collected from all three major geographical areas considered. The occurrence of the fungus on Syzygium spp. in KwaMbonambi on the Zululand coast, a major Eucalyptus forestry region where canker disease caused by $C h r$ austroafricana resulted in serious losses during the 1990s (28), might have suggested that the fungus spread from Eucalyptus to Syzygium spp. However, the other regions from which collections were made on the Zululand coast (Amanzimgwenya, Kosi bay, and Kosi mouth) are more isolated from Eucalyptus plantings. Furthermore, the occurrence of the fungus in the northern and eastern regions of the country, where cankers associated with $\mathrm{Chr}$. austroafricana are not common on Eucalyptus spp. even though susceptible trees are planted, was surprising.

The teleomorph of Chr. austroafricana was found frequently on samples collected from native Syzygium spp. This is particularly interesting, because teleomorph structures are rare on Eucalyptus and Tibouchina spp. in South Africa. For example, Van Heerden et al. (25) conducted an extensive survey of Chr. austroafricana (then known as Cryphonectria cubensis) in Eucalyptus plantations and failed to detect the sexual structures of the causal agent. However, sexual structures of the pathogen occasion-

Table 3. Lesion lengths resulting from inoculation with Chrysoporthe austroafricana on 1year-old Eucalyptus grandis (ZG 14 clones) and Syzygium cordatum trees 6 weeks after inoculation in the greenhouse

\begin{tabular}{lcc}
\hline & \multicolumn{2}{c}{ Lesion length $(\mathbf{m m})^{\mathbf{a}}$} \\
\cline { 2 - 3 } Isolate & S. cordatum & E. grandis \\
\hline CMW 2113 & 49.9 & 146.5 \\
CMW 9364 & 108.9 & 133.0 \\
Control & 10 & 10 \\
\hline
\end{tabular}

${ }^{a}$ Each value is the average of 40 measurements for each isolate.

${ }^{\mathrm{b}}$ Isolated from Eucalyptus sp.

c Isolated from Syzygium sp.; the isolate from Syzygium was more pathogenic than the one from Eucalyptus $(P>0.0001)$. 


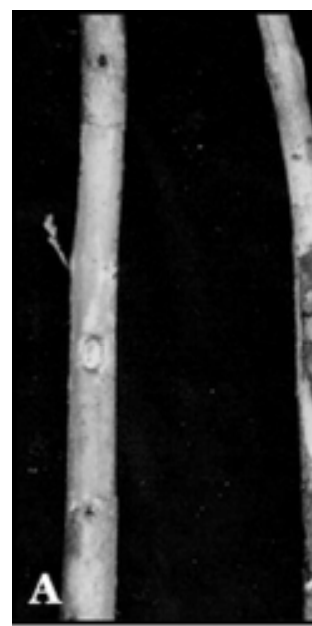

i

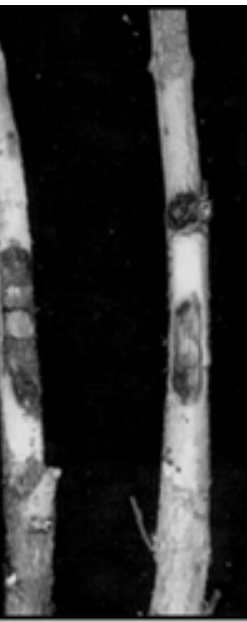

ii iii

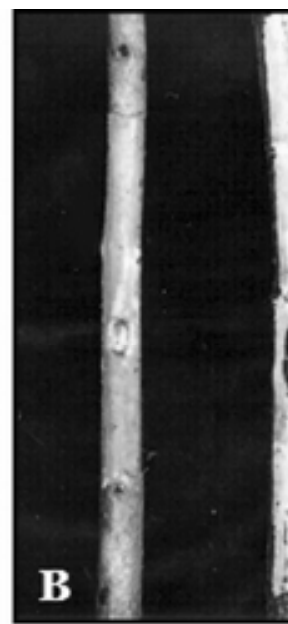

i

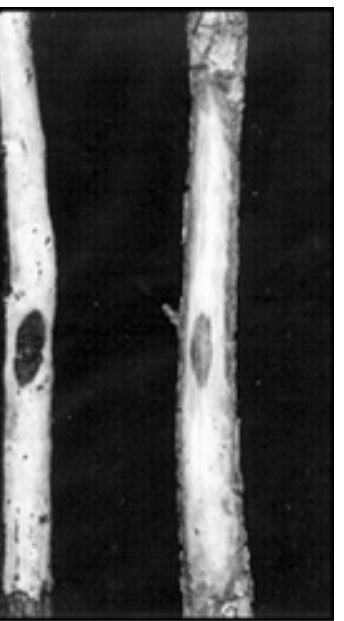

ii iii

Fig. 4. Lesions resulting from pathogenicity trials. A, Lesions formed on Eucalyptus grandis clones (Aii = CMW 2113; Aiii = CMW 9364) with control inoculation producing no lesions (Ai). B, Lesions formed on Syzygium cordatum trees (Bii = CMW 2113 and Biii = CMW 9364) with control inoculation producing no lesions $(\mathbf{B i})$.

ally have been found on Eucalyptus spp. $(8,29)$ and a limited number of times on Tibouchina spp. (13). If the fungus is native on Syzygium spp. and has adapted to infect Eucalyptus spp., recombination may be occurring on native hosts, resulting in new genotypes of the fungus able to infect Eucalyptus spp.

Pathogenicity trials in this study showed that $S$. cordatum is more tolerant to infection by Chr. austroafricana than the Eucalyptus clone tested. This suggests that the fungus may be native, because native hosts would be expected to be more resistant to infection than exotics $(11,16)$. S. cordatum trees inoculated in this study all were raised from seed and each plant represented a distinct genotype. In contrast, the Eucalyptus trees were all of a single genotype known to be susceptible to infection by Chr. austroafricana. Nevertheless, a highly pathogenic isolate from Eucalyptus spp. did minimal damage on inoculated $S$. cordatum trees, providing strong evidence for a relatively high level of resistance in the native South African tree. These data further support the view that the fungus could be native on $S$. cordatum.

Discovery of a native host for Chr. austroafricana in South Africa and the suggestion that the fungus on Eucalyptus originated on Syzygium spp. have important implications for forestry internationally. Previous studies have shown that Chr. austroafricana is considerably more pathogenic than the closely related $C$. cubensis $(19,20)$. Clearly, the South African fungus is a threat to Eucalyptus forestry in the rest of the world. Furthermore, it probably is not present in Australia and, if it were to enter that country, it could have a serious effect on native Australian Myrtaceae. In this regard, it is similar to the Eucalyptus rust $P$. psidii, which is considered as a major threat to the Myrtaceae in Australia (3). Thus, every effort should be made to restrict its spread from South Africa. Population diversity studies on the pathogen would also provide insight into the possible origin of Chr. austroafricana.

\section{ACKNOWLEDGMENTS}

We thank the members of the Tree Protection Cooperative Programme (TPCP), the National Research Foundation (NRF), and the THRIP initiative of the Department of Trade and Industry, South Africa for financial support; Ezemvelo KwaZulu Natal Wildlife and the Department of Water Affairs and Forestry (DWAF) for enabling us to perform the surveys and for the assistance of personnel in the surveys; and B. E. Eisenberg for assistance with statistical analysis of the inoculation trial data.

\section{LITERATURE CITED}

1. Bruner, S. C. 1917. Una enfermedad gangrenosa de los eucaliptos. Estacion Exp. Agron. Bull. 37:1-33.

2. Conradie, E., Swart, W. J., and Wingfield, M. J. 1992. Susceptibility of Eucalyptus grandis to Cryphonectria cubensis. Eur. J. For. Pathol. 22:312-315.

3. Coutinho, T. A., Wingfield, M. J., Alfenas, A. C., and Crous, P. W. 1998. Eucalyptus rust: A disease with the potential for serious international implications. Plant Dis. 82:819-825.

4. Davison, E. M., and Coates, D. J. 1991. Identification of Cryphonectria cubensis and Endothia gyrosa from eucalypts in Western Australia using isozyme analysis. Australas. Plant Pathol. 20:157-160.

5. Florence, E. J., Sharma, J. K., and Mohanan, C. 1986. A stem canker disease of Eucalyptus caused by Cryphonectria cubensis in Kerala. Kerala For. Res. Inst. Sci. Pap. 66:384-387.

6. Gibson, I. A. S. 1981. A canker disease of Eucalyptus new to Africa. FAO For. Genet. Res. Inf. 10:23-24.

7. Glass, N. L., and Donaldson, G. C. 1995. Development of primer sets designed for use with the PCR to amplify conserved genes from filamentous ascomycetes. Appl. Environ. Microbiol. 61:1323-1330.

8. Gryzenhout, M., Myburg, H., Van der Merwe, N. A., Wingfield, B. D., and Wingfield, M. J. 2004. Chrysoporthe, a new genus to accommodate Cryphonectria cubensis. Stud. Mycol. 50:119-142.

9. Hodges, C. S., Alfenas, A. C., and Ferreira, F. A. 1986. The conspecificity of Cryphonectria cubensis and Endothia eugeniae. Mycologia 78:343-350.

10. Larget, B., and Simon, D. L. 1999. Markov Chain Monte Carlo algorithms for the Bayesian analysis of phylogenetic trees. Mol. Biol. Evol. 16:750-759.

11. Leppik, E. E. 1970. Gene centers of plants as sources of disease resistance. Annu. Rev. Phytopathol. 8:323-340.

12. Lutzoni, F., Pagel, M., and Reeb, V. 2001 Major fungal lineages are derived from lichen symbiotic ancestors. Natute 411:937-940.

13. Myburg, H., Gryzenhout, M., Heath, R. N., Roux, J., Wingfield, B. D., and Wingfield, M. J. 2002. Cryphonectria canker on Tibouchina spp. in South Africa. Mycol. Res. 106:1299-1306.

14. Myburg, H., Gryzenhout, M., Wingfield, B. D. and Wingfield, M. J. 2002b. $\beta$-Tubulin and histone $\mathrm{H} 3$ gene sequences distinguish Cryphonectria cubensis from South Africa, Asia and South America. Can. J. Bot. 80:590-596.

15. Myburg, H., Wingfield, B. D., and Wingfield, M. J. 1999. Phylogeny of Cryphonectria cubensis and allied species inferred from DNA analysis. Mycologia 91:243-250.

16. Newhouse, J. R. 1990. Chestnut blight. Sci. Am. 263:74-79.

17. Posada, D., and Crandall, K. A. 1998. MODELTEST: testing the model of DNA substitution. Bioinf. Appl. Note 14:817-818.

18. Rayner, R. W. 1970. A Mycological Color Chart. Commonwealth Mycological Institute and British Mycological Society, Kew, Surrey, UK.

19. Rodas, C. A., Gryzenhout, M., Myburg, H., Wingfield, B. D., and Wingfield, M. J. 2005. Discovery of the Eucalyptus canker pathogen Chrysoporthe cubensis on native Miconia (Melastomataceae) in Colombia. Plant Pathol. 54:460-470.

20. Roux, J., Myburg, H., Wingfield, B. D., and Wingfield, M. J. 2003. Biological and phylogenetic analyses suggest that two Cryphonectria species cause cankers of Eucalyptus in Africa. Plant Dis. 87:1329-1332.

21. Sharma, J. K., Mohanan, C., and Florence, E. J. M. 1985. Occurrence of Cryphonectria canker of Eucalyptus in Kerala, India. Ann. Appl. Biol. 106:265-276.

22. Swofford, D. L. 1998. PAUP: Phylogenetic Analysis Using Parsimony (*and Other Methods) Version 4. Sinauer Assoc. Inc.: Sunderland, MA.

23. Thompson, J. D., Gibson, T. J., Plewniak, F., Jeanmougin, F., and Higgins, D. G. 1997. The CLUSTAL W windows interface: flexible strategies for multiple sequence alignment aided by quality analysis tools. Nucleic Acids Res. 25:876-882.

24. Van der Merwe, N. A., Myburg, H., Wingfield, B. D., Rodas, C., and Wingfield, M. J. 2001. Identification of Cryphonectria cubensis from Colombia based on rDNA sequence data. S. Afr. J. Sci. 97: 295-296.

25. Van Heerden, S. W., Wingfield, M. J., Coutinho, T., Van Zyl, L. M., and Wright, J. A. 1997. Diversity of Cryphonectria cubensis isolates in Venezuela and Indonesia. Pages 142-146 in: Proc. IUFRO Conf. Silvicult. Improvement of Eucalypts. Salvador, Bahia, Brazil.

26. Van Heerden, S. W., and Wingfield, M. J. 2001. Genetic diversity of Cryphonectria cubensis in South Africa. Mycol. Res. 105:94-99.

27. Wingfield, M. J. 2003. Daniel McAlpine Memorial Lecture. Increasing threat of diseases to exotic plantation forests in the Southern Hemisphere: lessons from Cryphonectria canker. Australas. Plant Pathol. 23:133-139.

28. Wingfield, M. J., Rodas, C., Wright, J., Myburg, H., Venter, M., and Wingfield, B. D. 2001. First report of Cryphonectria canker on Tibouchina in Colombia. For. Pathol. 31:1-10.

29. Wingfield, M. J., Swart, W. J., and Abear, B. J. 1989. First record of Cryphonectria canker of Eucalyptus in South Africa. Phytophylactica 21:311-313. 